\title{
CHARACTER AND CHARACTERIZATION IN GREEK TRAGEDY
}

\author{
BERND SEIDENSTICKER \\ Freie Universität Berlin
}

\begin{abstract}
RESUMO: Ao longo das últimas três décadas, tem-se travado uma vívida e controvertida discussão sobre a importância do caráter e da caracterização na tragédia grega. Na primeira e mais longa parte deste artigo, trato dos argumentos mais importantes que se apresentaram contra a interpretação baseada no caráter; na segunda e última parte, teço uma comparação entre Ésquilo e Sófocles, a fim de atentar para o alcance e forma da caracterização na tragédia de Ésquilo.
\end{abstract}

PALAVRAS-CHAVE: caráter e caracterização; tragédia grega.

\section{1. character and characterization in Greek tragedy}

The starting point of the debate is given by Aristotle's remarks about action and character and their interrelation. In the $6^{\text {th }}$ chapter of the Poetics Aristotle subsequent to his famous definition of tragedy - states that the most important of the six elements of tragedy is the "systasis ton pragmaton" (the arrangement of the different actions of a story into a cohesive dramatic plot) and goes on to substantiate his claim of the absolute priority of praxis (action) above ethos (character) by a long series of arguments (of which I will quote the first):

The most important of these elements is the structure of events, because tragedy is a representation not of people as such, but of actions and life, and both happiness and unhappiness rest on action. [...] It is not, therefore, the functions of the agents' action to allow the portrayal of their characters; it is, rather, for the sake of their actions that characterization is included. So, the events and the plot-structure are the goal of tragedy, and the goal is what matters most of all. 
At the end of his argumentation he calls the plot arché ( first principle) and psyché (soul, i.e. inner form) of tragedy.

Many critics have pointed to the $6^{\text {th }}$ chapter of the Poetics, when they argue that character and characterization do not play a significant role in Greek tragedy (or no role at all). Quite apart, however, from the fact that the Poetics - as is agreed by now - cannot be used uncritically as a key to the interpretation of Greek tragedy, one must keep in mind that Aristotle does not ignore the importance of the tragic character and his characterization, but repeatedly - in various contexts - talks about different aspects of the dramatis personae and their representation.

Thus in the $13^{\text {th }}$ chapter of the Poetics he adds to his definition of the ideal hero a specification, the function of which apparently is to define the social position of the main characters. The ideal hero, who, as a result of a hamartema, suffers the metabolé (the sudden reversal) from good to bad fortune, should belong to those, "who belong to the class of those, who enjoy great esteem and prosperity, such as Oedipus, Thyestes, and outstanding men from such families."

And indeed: the high social position of the main characters of Greek tragedy has not been challenged by ancient dramatists or theorists. Already Plato in his criticism of poets and poetry in the Republic and in the Nomoi proceeds from the self-evident assumption that tragedy (like epic poetry) portrays gods and heroes; and the agon between Aeschylus and Euripides in the Frogs of Aristophanes shows that the high social position of the tragic heroes already in the fifth century was considered as a distinctive mark of tragedy. When Euripides criticizes the bombastic style of Aeschylus, the attacked master of old tragedy replies that such a high style is required by the the special rank of his characters whom he calls "heroes and demigods": "As the Agon of the Frogs and the Platonic criticism of tragedy show, both Aristophanes and Plato saw the tragic heroes and heroines as the central element of tragedy".

Greater importance, however, than social position Aristotle attributes to the moral quality of the tragic hero. In the $2^{\text {nd }}$ chapter of the Poetics, in the context of his general remarks on the objects of artistic mimesis, Aristotle states, that measured against the average - comedy tends to represent people worse than ourselves, whereas tragedy portrays people, who are better than we are (1448 1618 ), and in the $4^{\text {th }}$ chapter, where he sketches the origin of art and the development of different forms of poetry, he argues: "And poetry was split into two types according to the poets' own character: the more dignified made noble actions the object of their mimesis, while lighter poets took the actions of base men" (1448b 24-26). 
This differentiation of genres under the aspect of the different moral quality of the people which they (re)present, has also not been invented by Aristotle either. It can be found in Plato and already the Aristophanic Aeschylus attacks Euripides' immoral women on the apparently self-evident assumption that tragedy in order to be able to educate the citizens must present morals models.

On the other hand Aristotle, in the $13^{\text {th }}$ chapter of the Poetics, explicitly says, that the superiority of the tragic hero over the average member of the audience must not be too great. For from the ultimate telos of tragedy, namely to produce eleos and phobos (pity and fear), there follow two conditions, which restrict the open comparative of chapter 2 "better than we". The hero, according to Aristotle, must not be "perfect" (epieikés), since the fall and ruin of a blameless man or woman would not arouse pity and fear, bur rather shock and upset our confidence in a just and rational world-order; and the tragic hero must be "similar to us", since only then his fate can create fear for him (and for us).

The requirement of similarity means that the hero should be familiar to us and understandable, that his thoughts and feelings, words and deeds must remain in the realm of our own experience of life, if his fate is to move us. Patricia Easterling in this context speaks of the "human intelligibility" of the dramatis personae. This does not mean that in the frame of this general similarity he could not, indeed should be better than the audience. The so-called "middle character", whom Aristotle in his definition of the ideal hero of tragedy has in mind, does not lie in the middle of the gliding scale from absolutely bad to perfectly good, but between the middle and the positive extreme. The short phrase, which Aristotle has added to his definition of the best tragedy, appears to stress exactly this: "on the part of the sort of agent I described - or of one who is better not worse than indicated."

At the end of the $13^{\text {th }}$ chapter Aristotle finally returns to this apparently important point and this time uses a comparison to elucidate what he means by the potentially misleading combination of the two requirements, that the tragic hero should be both "better than we" and "similar to us". The poet, he now states, should work like an artist; he should portray his objects as they are, as human beings with their strengths and weaknesses, i.e. as people like us, but at the same time he should idealize them, so that they are both better than we and yet true to life and representative of mankind.

Aristotle, of course, knows that the Greek tragedians did fulfill this requirement in quite different ways. He quotes a saying of Sophocles that he portrays human beings as "better than there are", whereas Euripides tends to present them 
"as they are". The fact that the heroes - as Simon Goldhill has pointed out - "are not contemporary nor (as a rule) from the same city of the audience nor of a similar status to the member of the audience", does not, in my opinion, create "a considerable barrier to treat them as individual or real people."

To his definitions of the social status and moral quality of the tragic hero Aristotle in the $15^{\text {th }}$ chapter of the Poetics adds four points, which a tragedian should keep in mind when creating the dramatis personae of his play. Two of them we have already seen: the heroes of tragedy should be good (chrestoi) and they should be similar to us (homoioi). The two other requirements are given in the $15^{\text {th }}$ chapter for the first time: Aristotle insists that the dramatic characters must be appropriate (harmotton), i.e. their attributes and qualities, their acting and thinking must match their sex, age, social origin and standing. And to this principle of suitability, which is well known from rhetoric, he adds the requirement of unity and consistency (homalón). In this context Aristotle stresses that the central poetic law of "necessity or probability", which governs the unity of action, applies to the creation of the characters also.

About the extent and form of characterization these general principles do not say anything. None of the four requirements, laid out in the $15^{\text {th }}$ chapter, demands a detailed characterization of the tragic heroes. And indeed: Aristotle in the $6^{\text {th }}$ chapter of the Poetics goes as far as arguing that even tragedies without ethos, i.e. tragedies, in which the dramatis personae are not developed as characters, are possible (1450a24-26). But this exaggeration appears to be a rhetorical argument to stress the priority of action against character. The unnamed poets of the fourth century, which Aristotle credits with this type of tragedy, certainly are not his ideal.

If one looks at the way, Aristotle compares the relation of action and character to the two most important elements of painting, line and colour, there can be no doubt, that he attaches a considerable importance to the embellishment of the dramatic action by colourful characters. "An analogous point holds for painting, where the most beautiful colours if smeared on at random, would give less pleasure than an uncoloured outline that was a picture of something" (1450a39 -b 3). As he could not imagine abstract painting, thus the important complementary function of colour and the superiority of a painting over a pure drawing certainly were self-evident for him.

As a matter of fact, the importance of characterization of the dramatis personae as an integral component of the mimesis of a dramatic action inevitably results from Aristotle's concept of praxis as a purposeful and ethically relevant 
human action. The subjects of a meaningful action must have a certain quality, which becomes evident in what they do and say and in the way they are doing and saying it and which imparts to the respective action a certain character. From this premise, which is valid for every mimetic art, Aristotle deduces in the $6^{\text {th }}$ chapter the two elements of tragedy which, next to the plot are the most important: dianoia, which signifies the intellectual quality of a person (and the ways it manifests itself in what they say) and ethos, which is usually translated as character, "for it is (I quote) through these (i.e. through ethos and dianoia) that we can also judge the qualities of their actions and it is in their action that all men either succeed or fail."

As Gill, Easterling, and Goldhill have pointed out, "in the Greek tragic texts there are extensive and complex vocabularies for the explanation of behaviour in term of human attitudes" (Goldhill); we everywhere find "explicit accounts of motives and grounds for deliberate choice, in which the agent expresses his character" (Gill), and the poets often explicitly call upon the audience to think about the motivations and feelings of the dramatis personae: "There comes Haemon. Does he come in tears for his bride? (Ant. 700ff.).

The second objection, however, against a character-oriented interpretation of Greek tragedy is not sufficiently taken into account with the argument that Aristotle does (indeed) pay attention to the character of the tragic heroes. Critics stress the fact that the Aristotelean term ethos is considerably narrower than the modern concept of character, for which, at least since the $19^{\text {th }}$ century, the notion of a unique and singular individuality and puzzling complexity is constitutive. Ethos, on the other hand is to be understood as moral disposition acquired and reinforced by education and repeated action, as the moral nucleus, which is the basis for all our wishes, intentions and decisions. Thus ethos, indeed, does not point to the idiosyncratic uniqueness and colourful complexity of an individual, but to definite and general moral qualities. The modern psychological concept of character automatically leads to the understanding, that each and every gesture or action of a real or fictitious person, be it ever so inconspicuous, and each and every remark, be it ever so incidental, allows inferences about his or her character. Aristotelean ethos on the other hand manifests itself - as in life, so in tragedy - only and exclusively, where and when actions and remarks indicate the moral quality of a decision, which leads to and determines the action of a person, and thus signifies his or her inner nature (Wesenskern): "The mimesis of character is that (in the play) which makes plain the nature of the moral choices the personages make, so 
that those speeches in which there is absolutely nothing the speaker chooses or avoids involve no mimesis of character" (1450b 8ff.).

Hence it follows inevitably that the characterization of the dramatis personae of tragedy for Aristotle cannot be an end in itself, but a function of the dramatic action. At the same time, however, it follows that - at least in a good tragedy - the moral and - as his explanation of dianoia shows - the intellectual roots of the actions and reactions, out of which the dramatic structure of the play is built, must be made recognizable. In the $9^{\text {th }}$ chapter of the Poetics Aristotle elucidates the philosophic quality of poetry with a formulation, which stresses the interdependence of action and character: "Poetry tends to make general statements while those of history are particular. A 'general statement' (in this context) means, one that tells us, what sort of man would, probably or necessarily, say or do what sort of thing" ( 1451 b 6-9).

Apparently Aristotle insists on such a degree of characterization of the dramatis personae that the audience can understand, that and why they act and talk in the way the dramatic action, as conceptualized by the poet, requires them to act and talk. We thus, even if we accept for a moment the Aristotelean position as valid for the Greek tragedians, are dealing with a quantitative, and not with a qualitative difference (i.e. a difference in degree, not in principle) between ancient and modern tragedy; and the fact that the characterization in Greek tragedy is less detailed than in the drama of the $18^{\text {th }}$ and $19^{\text {th }}$ centuries does not mean, that it is less significant.

The same is true for the third argument or rather series of arguments, brought forward against the importance of character and characterization in Greek tragedy, arguments which are based on the conditions of the production and reception of classical tragedy. It is obvious that the Greek theatre imposes a number of restrictions (up)on the dramatists, which are of importance for the form and technique of characterization. The fact that the male actors had to play all female parts and that in the course of a tetralogy they had to slip into many different roles (sometimes even two actors shared one role) is negligible. Important, however, is the standardized costume of tragedy. Minor variations and modifications could point to origin, status, and situation of a dramatis persona; but in general costumes and accessoirs could not be used - as they are used in modern drama - to signify a unique individuality or indicate a certain character quality or emotional disposition. Of even greater importance is the mask, since it excludes a central medium of characterization, i.e. the mimic expression as mirror of thoughts, feelings and 
emotions. If one looks at stage-directions in plays by Henrik Ibsen, George Bernhard Shaw or Eugene O'Neill, the importance of this instrument of characterization is evident.

And important, finally, is also the size of the ancient theatre. The mask deprives the actor (and thus the poet) of the almost infinite expressiveness of the human face; the enormous distance of the audience forces the actors to an unambiguous, stylized and conventionalized form of acting, which dispenses with the more subtle nuances of body-movement and gestures, which in modern plays can be an important medium of characterization.

One should, however, not overestimate the consequences of these conditions and conventions of the ancient theatre for the extent and quality of characterization. Size of the theatre and masks do not allow a detail-loving realism. They result in simplification, abstraction and stylisation, but they do not prevent the mimesis of complex and individual dramatis personae. To concentrate on the essentials does not mean to dispense with individuality. Of crucial importance for the question, whether a dramatis persona appears as type or as individual character, is, what he does and especially what he says. And language - as the means to unfold in great detail and subtlety, what drives a person to act in the way he (or she) acts, is not seriously limited by the special conditions and conventions of the ancient theatre.

On the other hand critics in this context love to point out, that the language of tragedy is a highly stylized and homogenous medium, which is spoken by all dramatis personae alike. A realistic mimesis of different levels of speech and of idiosyncratic diction and manner of speaking does only exist in small traces, if at all. But this is true for modern tragedy well into the $19^{\text {th }}$ century and - as a brief look at Shakespeare or Racine, Goethe or Schiller - can show, did not seriously impair the creation of psychologically complex characters.

With better reasons critics of a psychological analysis of the characters of Greek tragedy have drawn attention to the fact that the utterances of the tragic heroes and heroines often - especially in Euripidean tragedy - seem to be governed more by the commonplaces and rules of rhetoric than by their individual character or by a special mental or emotional state (Befindlichkeit). Indeed, one has to be cautious; especially long monologues and the rheseis in many a dialogue bear the stamp of rhetoric. When reading or watching Greek tragedy one has to keep in mind, that not every argument and not every formulation of an argument serves to illuminate the character of the speaker. Often the Greek tragedians use the dramatis 
personae in the first place, to unfold the various aspects of a dramatic situation or the different positions of a problem clearly and comprehensively. This is obvious in plays, for which the individual quality of the dramatis personae is of little importance as in the two suppliant plays of Euripides (Heracleidae and Suppliants) or in his Trojan anti-war plays (Hecuba and Trojan Women). But we have to be cautious also in cases, where action and character are much more closely related as f. e. in Alcestis and Medea, Hippolytus and Bacchae.

On the other hand rhetoric and individual characterization do not necessarily exclude each other. Thus the long captatio benevolentiae, by which Medea in the first epeisodion of the tragedy successfully tries to win the sympathy of the Corinthian women of the chorus is a masterpiece of rhetorical composition and argumentation and at the same time the exposition of a crucial quality of the heroine. The sudden change from the storm of emotions, by which Medea, as Euripides presents her indirectly in the prologue and in the parodos, is driven, to the cool rhetoric and analytic rationality of her first long speech should not be misunderstood as proof for Euripides' lack of interest in the inner unity of Medea's character. It rather is a first and powerful testimony, that Medea is able to subordinate her wildest emotions to her outstanding intelligence, whenever it seems necessary for the achievement of her goals, and it is this capability to manipulate her male opponents and friends (Creon, Jason and Aegeus) by her superior intelligence, which enables Medea, who, after Jason has betrayed her, sets out from a state of utter helplessness, to reach her triumphant victory over the traitor. At the same time the tension between emotion and rationality, which can be felt in her first long speech, prepares the audience for the deep tragic conflict, which is going to break out and almost destroy her in the great monologue before the murder of her children. The example shows that the rhetorical quality of an utterance does not mean, that the passage is irrelevant for the characterization of the speaker.

The same holds true for a third factor, which determines the form of the mimesis of individual characters in Greek tragedy: the conventional structures of verbal communication. When interpreting a stichomythia or an agon one certainly should keep in mind that the utterances of the dramatis personae often are determined by the formal rules and inner logic of the respective structure to a higher degree than by the character of the speaker. On the other hand it often can be shown (and has been shown e.g. by Schwinge), that a seemingly irrelevant line or half-line of a stichomythia, which has been criticised as a mere stopgap, on closer inspection can indeed reveal the mental or emotional state or a significant character trait of the speaker; and the heated quarrels between Medea and Jason 
or between Creon and his son Haemon can show that the Greek dramatists could present an agon, despite its rather rigid conventional form as a vivid interaction between two distinct personalities, whose character does have a significant influence on form and development of the discussion. The assumption, that the high degree of formal stylization, by which Greek tragedy is characterized, necessarily implies that the tragedians were not interested in the psychological truth and inner unity of the dramatic characters they created, therefore is wrong.

To sum up: neither the different notion of character nor the specific conditions and conventions of the Greek theatre seriously impair the mimesis of individual, coherent and psychologically convincing dramatis personae. It is selfevident that the critic of Greek tragedy must be familiar with the multifarious dramaturgic and formal conventions, which determine the forms and techniques, in which character can be created and presented. Otherwise he may foster expectations and ask questions, which are derived from naturalistic forms of modern theatre. On the other hand the size of the Greek theatre and its conventions; the sparing economy of the dramatic technique used by the Greek tragedians, the high degree of formal stylization, and the unrealistic alternation of totally different forms of expression, reminiscent of the opera, do not necessarily prevent subtle characterization and the creation of complex characters.

Extent, form and function of characterization are not dependent (up)on the outer conditions of production, but on the specific thematic intentions of the dramatist. Simple generalizations therefore are dangerous. The differences not only between the three tragedians, of whom we possess complete plays, but also between the various plays of an author or between the dramatis personae of a single play are considerable. Nobody would reduce the representation of the dramatis personae of Aeschylus' Persae and Sophocles Philoctetes or of the suppliant plays of Euripides and his Medea or Bacchae to a common denominator.

In the following second part of my paper I will first try to sketch the differences between Aeschylus and Sophocles and than look at extent, form and function of characterization in Aeschylean tragedy.

\section{Aeschylus and Sophocles}

The difference between Aeschylus and Sophocles with regard to the importance of character and characterization is already signalled by the titles of their tragedies. Five of the six Aeschylean plays are named after the chorus (Suppliants) or after the mythical or historical subject matter (Persians; Seven against 
Thebes) or their titles refer to important scenes or themes of the plays (Libation Bearers, Eumenides). The title Agamemnon certainly does not refer to Agamemnon as the central tragic hero of the play. It probably was chosen to point to the central action of the tragedy: Agamemnon's return and murder. Six of the seven Sophoclean tragedies, on the other hand, bear the name of the hero, whose fate they present; and in the case of the double tragedy Trachiniae, in which Heracles and Deianeira mutually destroy each other, the title appears to be due to the difficulty to decide which of the two protagonists is the dramatic, emotional or thematic center of the play.

To be sure, we cannot be certain, who is responsible for the titles, under which the tragedies have been transmitted to us. But, whoever named the plays, the conspicuous difference between Aeschylus and Sophocles cannot be a mere coincidence. For it signals the fundamental difference in the conception of the tragic and in the resulting dramatic technique.

Sophocles' main theme is the tragic confrontation of an outstanding individual with his personal fate. As Knox has stressed, it is this conception which makes Sophocles the protos heuretes of classical European tragedy: "This dramatic method, the presentation of the tragic dilemma in the figure of a single dominating character, seems to be an invention of Sophocles. It is at any rate so characteristic of his technique that we may fairly and without exaggeration call the mainstream of European tragedy since his time Sophoclean." Thus the testimony, that Sophocles gave up the tetralogical form and entered the competition with single (unrelated) plays, makes good sense. For the single play allowed him to focus all light on his solitary giants (as Karl Reinhardt has called the Sophoclean heroes) and their fate. This is immediately evident, where we can compare his treatment of a mythical story with the versions of Aeschylus and Euripides. In his Electra e.g. Sophocles has reduced the central action of the myth - Orestes' homecoming and the matricide - to a small outer frame and concentrates on the portrayal of Electra. Whereas Aeschylus and Euripides are primarily interested in the accomplishment and evaluation of the revenge, Sophocles uses the story as background and catalyst for his exploration of a great soul. The tragic situation of his play does not lie in the objective (Aeschylus) or subjective (Euripides) problems of the matricide, but arises out of the physical and psychological suffering and unbearable isolation, which threatens to destroy the heroine.

In Sophoclean tragedy the character of the hero is an essential part of his tragic dilemma. The situation, in which his fate is fulfilled, does come from the outside. But it fulfils itself - or fulfils itself in the way it fulfils itself - only because 
the hero is what he is. In the moment, however, in which the tragedy does arise out of a complex interplay of outer circumstances and the nature of the hero (and not or not alone out of a divine command, an old curse or a religious or social obligation) the character of the hero must be elaborated at least the a degree that the audience can understand his tragedy and the special form, in which it evolves and is brought to a close, as natural and cogent (or as Aristotle said, as "necessary or probable").

In this respect ancient and modern critics agree. The Life of Sophocles states: "He knows how to arrange the action with such a sense of timing that he creates an entire character out of a half line or a single expression", and we have a precious piece of evidence, in which the importance Sophocles attributed to this aspect of his art, is confirmed by the poet himself. Plutarch transmits a statement, in which Sophocles confesses that he rather late, in the third phase of his development as a tragedian, had arrived at the style which could bring out the ethos of his dramatis personae perfectly and therefore was the best. The formulation suggests that Sophocles was speaking of the final perfection of his poetic language, but the statement is valid for his dramatic style in general and points to the essence of his thematic intentions. In Sophoclean tragedy character and characterization are of considerable importance, and although Knox is certainly right, that all Sophoclean heroes bear the same stamp, Sophocles has managed to give all of them a distinct individual quality. In an article on character and characterization in Sophoclean tragedy I have outlined some elements of Sophocles' technique of characterization.

Aeschylus, on the other hand, as a rule dramatizes the fate of an empire, a group or a family. The single human being - as agent or passive victim - is not important as tragic individual (as in Sophoclean tragedy), but as part of a development, which reaches far beyond him into the past and into the future. His actions and sufferings interest Aeschylus as factors which trigger, promote or hinder this greater story, and, if at all, only in the second place as actions and sufferings of a individual. A central theme of Aeschylean tragedy is the analysis of fundamental religious and social tensions and conflicts and how they can be solved or overcome in compromises, which are guaranteed by the gods and stabilized by human institutions. The ideal dramatic form for these syntheseis, which are reached through thesis and antithesis, is the trilogy (or tetralogy), which Aeschylus, if he was not its inventor, certainly has brought to perfection.

As the Persians show, the secondary importance of character (in comparison with action), cannot be understood as a function of Aeschylus' favourite dramatic form. Just as in the other transmitted plays, which belong to trilogies, the poet in 
the Persians is not interested in the personal tragedy of Xerxes (or other persons). The catastrophe of the Persian fleet at Salamis serves to demonstrate the victory of freedom over barbarism and - as the consequence of hybris - the downfall of the Persian empire and its imperialistic ambition. Hence there is no need neither for detailed portrayal of the character of the dramatis personae nor of their personal relations. The dramatis personae of the play are little more than the council of elder statesmen, the mother, the wise dead king, and his impetuous young successor.

Aeschylus with a few strokes has drawn them just so that they appear as convincing agents of his paradigmatic action: the chorus of old men: council of the empire and voice of its people, who are worried first about the fate of the army empire and then lament the dead and the misery of their families; loyal, but in a growing critical distance to their king; Atossa, the mother of the king, driven by anxieties and ominous dreams, all mother and woman, who but in the moment of the impending catastrophe begins to reflect upon the expedition of her son against Greece and who, when the disaster is certain, can think about nothing, but whether her son is safe and how she can help to protect his authority as king and preserve the power of the throne ; the old wise king Dareios, who, when he is summoned up from his grave, immediately grasps the deeper roots of the catastrophe and is able to draw the conclusions and formulate the wider lessons from what has happened; and the young king, proud and impetuous, blinded by the splendour and power of the Persian empire and driven by personal ambition, who rushes into an adventure, which ruins his army and threatens to ruin his empire.

Aeschylus as a rule bestows upon his dramatis personae just enough 'character' that the audience can perceive the development of the dramatic action as "necessary or probable". In the Persae a few lines suffice to lay open the personal roots of Xerxes' hybris:

Wicked men counselled this,

Saying you acquired wealth

By spear, while he, in cowardice, played

The warrior at home, and multiplied

By nothing his ancestral wealth. So often

These wicked men reproached him, until he

Did plot his martial way toward Greece (753ff.)

Where the character of the agents is irrelevant for the tragic situation, as in the Suppliants, Aeschylus does not characterize them at all. Pelasgus, the king of 
Argos, out of the blue is confronted with the question, whether he ought or rather must risk the peaceful existence of his country to safe a group of foreign women, who have sought asylum at the altar of Zeus. The tragic dilemma, which offers him the choice between his religious obligation to protect the suppliants, who threaten to hang themselves on the altar, if he does not help them, and his political duty as king to guard his people from a war against a powerful enemy, does confer tragic stature upon Pelasgus. Individual features, however, which would turn the agent of a momentous tragic action into a complex character, are absent.

Just a trace of individual characterization can be seen in the representation of the hero of the Seven against Thebes: The central figure of the last play of the Theban trilogy is Eteocles, one of the two sons of Oedipus, who has to defend Thebes against the Argive army, led against the city by his brother Polyneices, who wants to win the throne, which his brother refuses to concede to him voluntarily, as the two brothers had agreed. This Eteocles at the end of the long scene, in which he selects the best-suited defenders for the seven gates of Thebes, suddenly must realize, that as a result of his decisions, which were militarily necessary and tactically shrewd, the seventh and last gate, where his brother is going to attack the city, is left to himself. When he recognizes, that he cannot escape the curse of the Labdacids, he makes the fated deed his own. Only here, in the heated debate with the chorus, who attempts to hold Eteocles back, Aeschylus has given the hero interesting touches of an individual character, and the reason is obvious. Whereas the decision-scene of the Suppliants presents an abstract tragic conflict of duties/obligations, Aeschylus in the Seven against Thebes wants to explain the sudden change, which turns the competent and responsible defender of the city into a vindictive egomaniac, who desires to kill his brother. This is the reason, why the characterization of the hero in this scene and in this scene alone - is detailed and subtle.

The only complete trilogy of Aeschylus, which we possess, on the one hand confirms the picture presented by the other tragedies, but, on the other hand, offers a number of interesting innovations. Nowhere is the subordination of character and characterization under action and thematic intentions more evident than in the Eumenides. Here the human and divine agents are little more than incorporations of the theological, legal and moral positions, they represent and defend. In the Choephori the protagonists, as a brief comparative look at the Sophoclean and Euripidean versions of the story can show, also are above all functions of the revenge-plot: the son of the victim who has to return home and take revenge for the murder of his father; the daughter, who pines away with laments about her father and longing for the brother; and the murderess, who, when Ores- 
tes brings the false news of the death of her son, for a last short moment can delude herself with the illusion of security, but only to be confronted with the cruel reality of the revenge. Even in the decisive scene, when Orestes with the sword stands in front of his mother, Aeschylus is primarily interested in the precise analysis of the tragic dilemma, which Orestes faces. This is not to say, that he totally ignores the psychological aspects of the matricide and abstains from all individual traits in the representation of Orestes and Clytaemnestra. Aeschylus here (as in other scenes) proves himself to be a master of dramatic economy. Two lines - Clytaemnestra's call for an axe (889) and Orestes helpless turning to his friend (what shall I do? 899) suffice to reveal the terrifying power and wild determination of Clytaemnestra, who, to safe her life and maintain her position, is ready to kill her son also, and the elementary reserve of Orestes in face of the horrible deed, though it is ordered by Apollo. Thus Aeschylus manages to direct the emotions of the audience in the intended direction.

While this technique of a psychologically significant detail remains within the frame, of what is familiar from the other tragedies, the Choephori also present something new. The representation of the protagonists and the relation between them is not sketchy throughout. Aeschylus opens the play after prologue and parodos with an unusually detailed portrayal of Electra and a rich orchestration of the anagnorisis of brother and sister at the grave of their father. He does not only present the grief and misery of Agamemnon's daughter, who can not bear to live under the same roof as the killers of her father, but also the helplessness of the young girl, who, in her concern not to become like the mother, at first does not dare to openly confess her desire for revenge; he presents Electra's desperate longing for her brother and the anxiety to be deluded by her sudden hope that he may have come back, and he presents - less detailed, but unmistakable - the gentle tenderness, with which Orestes makes allowance for the vulnerability of his sister.

No question: Aeschylus in this scene develops the personal disposition of the dramatis personae and the emotional aspects of their meeting in much greater detail than usual. The accuracy and empathy of the representation reminds us of Sophocles' art of characterization. The unusual technique is no end in itself. Its function is manifest. The affectionate scene between brother and sister serves as foil and contrast for the brutal destruction of all family ties in the Agamemnon, and the innocent purity of the avengers of Agamemnon on the one hand intensifies the gruesomeness of the deed, which they have to carry out, and on the other hand is the basis for the overcoming of the ius talionis in the Eumenides. These avengers deserve to be rescued by the gods. 
Most detailed and complex is the characterization of the dramatis personae in the Agamemnon. In the first play of the trilogy even the chorus of old men shows traits of individuality, especially in the parodos and in the scenes after the murder of Agamemnon, and the minor characters also are drawn with individual touches. Aeschylus opens the play with the masterful vignette of the drowsy watchmen, who laments about his lousy job, intimates, that something is wrong in the state of Argos, and yearns for his master's return; and the herald, who reports the victory and announces the imminent return of Agamemnon, is characterized in much greater details than the usual messenger.

Together with Orestes' nurse in the Choephori these figures (and some of Sophocles minor characters, like the guard in the Antigone) open a long and rich tradition, which reaches its climax with the lively minor characters of Shakespearean tragedy.

Of greater importance than the colourful representation of the minor characters is the complexity with which Aeschylus at the climax of the play has drawn the three protagonists and the deadly triangle in which they are connected. On the chariot the king, who after ten long years returns with a concubine from the war, for which he has sacrificed his daughter; at the threshold the queen, who for years has waited for the murderer of her daughter; and behind the king on the chariot, the prophet, who sees through Clytaemnestra's trap and foresees everything, but will not be able to save the king and herself - and does not want to.

Agamemnon's role is the shortest of the three and his portrait is more conventional than the other two. Yet already by the graphic picture the chorus has drawn of the king in the crucial situation in Aulis, he is given sharper contours than the other Aeschylean kings Danaus and Pelasgus, Xerxes or Eteocles: With a few masterly strokes Aeschylus here sketches not only the outer pressures, which weight down on Agamemnon (the deterioration of the ships, the consumption of the provisions, the boredom of the soldiers and the expectations of the fellow commanders), but also the inner conflict between Agamemnon's love of his daughter, the feeling of his duty as king of kings, the divine order and his personal urge for leadership and glory (184-237).

In the short scene between the grand entrance of the victorious king of kings and his ominous exit into the palace over the blood red fabrics, which Clytaemnestra has laid out in front of the door, Aeschylus behind the proud pose of the mighty victor exposes the arrogance of power and the weakness and blindness of a man, who without any sensibility for the guilt, which he has incurred on his way to Troy and in Troy, and thus must remain deaf to the implicit warnings of the chorus and to 
the threats, his wife hardly hides behind the exaggerated flatteries, with which she bids him welcome. Hence it becomes clear and understandable, how this man could sacrifice his daughter and that he now so easily falls prey to Clytaemnestra.

Despite the relatively high degree of individuality, which Aeschylus has given to his Agamemnon, the technique of characterization insofar stays within the normal boundaries, that Aeschylus has confined himself to the character traits, which are necessary to let the action appear as probable and plausible. This, however, cannot be said about the two female protagonists of the Agamemnon. Whereas the representation of Cassandra in her visions of the past and her presentiments of the future is based on traditional forms of prophetic madness and primarily a function of her dramatic role, person and fate of the Trojan princess in the moments of her tragic isolation assume a dimension, which reaches beyond her dramatic function: in the puzzling cries, with which she breaks her long silence and in the painful resolution, with which she renounces Apollo, but also in the little scene, in which she without speaking a single word, puts Clytaemnestra in her place, who a moment ago has played cat and mouse with Agamemnon, and especially at the end, when she, through all her fears and apprehensions, forced, yet out of her own will, mourning, yet unbroken, goes into the palace and into her death. No wonder that Christa Wolf, when she read the Oresteia was so moved by the fascinating personality of Cassandra. This figure of Aeschylus clearly trespasses the line, which Aristotle draw with his thesis of the absolute priority of the action over the characters.

And the same is true also - and to an even greater degree - for Clytaemnestra, the most powerful and complex Aeschylean character: "the woman with the planning heart of a man" (11), a queen with impressive/awe-inspiring strength and shocking ruthlessness. She lives in the small worries of the watchman and in the momentous anxieties of the chorus; until the murder of Agamemnon she manipulates and controls language and action with sharp intelligence and rhetoric brilliance and with the shameless audacity of her flattery, and she is no less fascinating after the murder in the triumphant jubilation, with which she acknowledges the deed, in the pessimistic tiredness and resignation, which gradually overcome her, and in the growing dread of the daimon, whose instrument she has just been and whose victim she now fears to become.

\section{Conclusion}

If I had the time - or another lecture - I could look at Euripides, whose oeuvre presents a highly diversified picture. Among the seventeen preserved plays, 
there are some, on which - as in Aeschylus - there appears to be no or little interest in characterization (as e.g. in the two suppliant plays), and others, in which we find elaborately and consistently drawn characters in the Sophoclean manner (as e.g. Medea, Hippolytus or Bacchae.). Two aspects would be of particular interest: Euripides' mastership in drawing weak and hollow pseudo-heroes like Admetus or Jason, Menelaus or Orestes and the deep psychological insight of the poet, who created figures like Medea, Phaedra and Creusa, or Hippolytus and Pentheus.

Instead I conclude with a general remark which brings us back to the first part of my paper:

Like all literary figures the dramatis personae of a tragedy differ categorically from real people as we meet them outside the theatre. As poetic creations they exist only and exclusively ion what they say and do, live only for the duration of the play and only in the world of the play. This limitation of the dramatis persona (in contrast to the infinite openness and bewildering complexity of the real person) implies that we cannot know everything about them, that we may want to know; but it also implies that, within the limits drawn by the author, we can know everything about them, whereas our knowledge of a real person is always less than complete. For the interpretation of Greek tragedy (as for all poetry) this means that we have to stay within the paradoxical confines of this 'incomplete completeness' and that we - in our search for the attributes and motivations of a character - should neither ask questions, which the text does not allow, nor omit questions, which the text appears to request. Wilson Knight's famous ironical question: "How many children had Lady Macbeth?" can be paralleled by many inadequate questions, which have been posed to Greek tragedies or their heroes, as e.g. Voltaire's astonishment, why Oedipus and Iocaste had not earlier talked about the deformed feet of the king, or Wilamowitz' sarcastic apercu, what Alcestis, after her return from the dead, might have said to Admetus at their next breakfast.

The rigorous economy of means, with which the Greek tragedians work, as a rule limits the information about the nature, qualities and actions, believes and of the characters to what is essential for the understanding of the action. Many things we would like to know in addition, remain in the dark, and all attempts to uncover them, must lead to pure speculation. On the other hand - as we have seen - the technique of the significant detail, so masterly used by the Greek tragedians, does allow more conclusions about the character of the dramatis personae than the minimalists are ready to concede. 
SEIDENSTICKER, B. Character and characterization in Greek tragedy. ABSTRACT: Over the last three decades there has been a lively and controversial discussion about the importance of character and characterization in Greek tragedy. In the first and slightly larger part of my paper I will deal with the most important arguments, which have been brought forward against a character-oriented interpretation, and then after a short comparison of Aeschylus and Sophocles look at extent and form of characterization in Aeschylean tragedy.

KEYWORDS: character and characterization; Greek tragedy. 